\title{
An editorial comment for the special series "Upper-Tract Urothelial Carcinoma: Current State and Future Directions"
}

We are honored to have been invited to edit this series of Translational Andrology and Urology (TAU) on "Upper-Tract Urothelial Carcinoma: Current State and Future Directions".

As a rare disease, upper tract urothelial carcinoma (UTUC) presents a unique challenge to urologists. Often difficult to diagnose and stage, frequently recurrent without radical surgery, and typically occurring within a highly comorbid patient population, management of UTUC leads to a series of difficult clinical decisions for patient and surgeon. Compounding this challenge is the burden to generate large clinical numbers for research, in order to move the practice forward. While guidelines are in place to provide structure to the treatment modalities, there remains a great deal of nuance to the care of patients with UTUC. Therein lies the rub.

This focused edition of TAU will explore a breadth of topics surround UTUC, to bring into focus up-to-date discussions. Highlighted topics include epidemiology, risk stratification and the challenges of diagnosis; outcomes of organ-sparing surgery, tips and tricks, and future directions; outcomes of radical surgery including complications, the role of lymph node dissection, the role of perioperative chemotherapy, management of the bladder cuff, and bladder recurrence following UTUC. It is our endeavor that this collective work provides an exploration of the nuance surrounding UTUC, allowing urologists to offer improved outcomes to their patients.

We thank the authors for the remarkable time and effort put forth, which made this special series possible. We are privileged for their contribution, and hope that the totality of their work will make a meaningful contribution to your practice.

\section{Acknowledgments}

The Ken and Bonnie Fund for Urologic Cancer Research at Penn State Health; The Keith and Lynda Harring Fund for Urologic Research at Penn State Health.

Funding: None.

\section{Footnote}

Provenance and Peer Review: This article was commissioned by the editorial office, Translational Andrology and Urology for the series "Upper-Tract Urothelial Carcinoma: current state and future directions". The article did not undergo external peer review.

Conflicts of Interest: Both authors have completed the ICMJE uniform disclosure form (available at http://dx.doi.org/10.21037/ tau-2019-utuc-15). The series "Upper-Tract Urothelial Carcinoma: current state and future directions" was commissioned by the editorial office without any funding or sponsorship. JJK and JDR served as the unpaid Guest Editors of the series. The authors have no other conflicts of interest to declare.

Ethical Statement: The authors are accountable for all aspects of the work in ensuring that questions related to the accuracy or integrity of any part of the work are appropriately investigated and resolved.

Open Access Statement: This is an Open Access article distributed in accordance with the Creative Commons AttributionNonCommercial-NoDerivs 4.0 International License (CC BY-NC-ND 4.0), which permits the non-commercial replication and distribution of the article with the strict proviso that no changes or edits are made and the original work is properly cited (including links to both the formal publication through the relevant DOI and the license). See: https://creativecommons.org/licenses/by-nc$\mathrm{nd} / 4.0 \%$. 


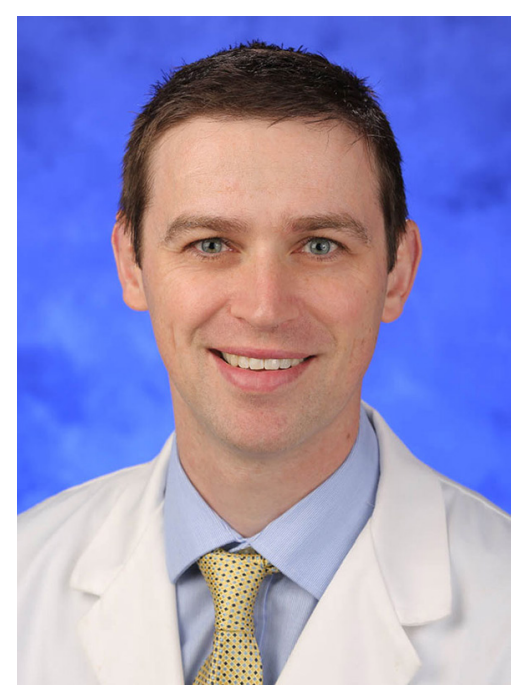

John J. Knoedler

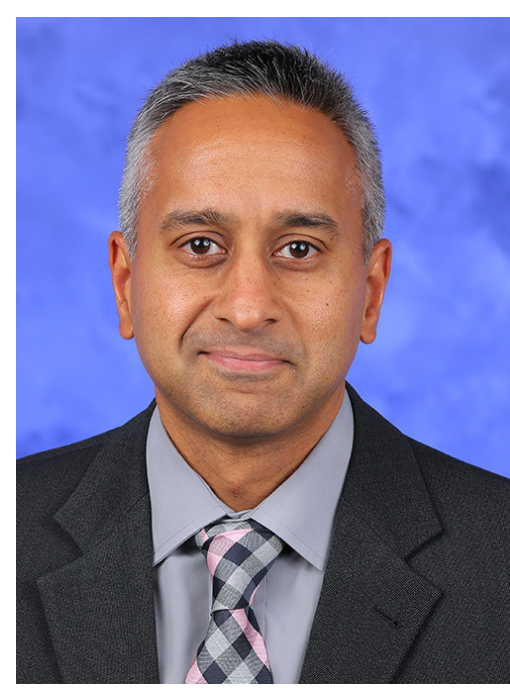

Jay D. Raman

John J. Knoedler, MD

Assistant Professor of Urology, Penn State Health Milton S. Hershey Medical Center, Hershey, PA 17033, USA. (Email:jknoedler@pennstatehealth.psu.edu)

Jay D. Raman, MD, FACS

Professor and Chief of Urology, Penn State Health Milton S. Hershey Medical Center, Hershey, PA 17033, USA.

(Email:jraman@pennstatehealth.psu.edu)

Submitted Mar 31, 2020. Accepted for publication May 07, 2020. doi: $10.21037 /$ tau-2019-utuc-15

View this article at: http://dx.doi.org/10.21037/tau-2019-utuc-15

Cite this article as: Knoedler JJ, Raman JD. An editorial comment for the special series "Upper-Tract Urothelial Carcinoma: Current State and Future Directions". Transl Androl Urol 2020;9(4):1778-1779. doi: 10.21037/tau-2019utuc-15 